\title{
Voivodeship Classification in Accordance with the Directions of Agricultural and Forest Lands Repurposement
}

\author{
Agata Pawłat-Zawrzykraj ${ }^{1 *}$, Konrad Podawca ${ }^{1}$ \\ 1 Warsaw University of Life Sciences, Faculty of Civil and Environmental Engineering, Department of Remote \\ Sensing and Environmental Assessments, ul. Nowoursynowska 166, 02-787 Warsaw, Poland \\ *Corresponding author's email: agata_pawlat_zawrzykraj@sggw.pl
}

\begin{abstract}
Spatial policy-making and implementation at the national and regional levels require, among others, long-term monitoring of socio-economic processes in the spatial and statistical dimension. The paper focuses on the issue of land-use changes for non-agricultural and non-forest purposes in individual provinces (called voivodeships). A special emphasis was put on the intensity and direction of the transformation processes. In order to compile the results in the form of a comparative analysis, a multi-indicator method was developed with the use of the data provided by Local Data Bank for the years 2003-2017. The results illustrate both variations and similarities in the spatial development between the analyzed voivodeships.
\end{abstract}

Keywords: land use, spatial development, regional development.

\section{INTRODUCTION}

The research on regional development constitutes the basis for making strategic development objectives for the country, regions and various sub-regional spatial structures (Dunnell, 2009). This kind of monitoring and evaluation provides the information on the progress in implementation of strategies and public polices (KSRR, 2030). The studies create recommendations that are useful not only to regional government but also to business organizations as well as domestic and foreign investors.

Numerous reports in literature approach the issue in a complex and multifaceted way. Assessments include the following: the development potential of regions, investment attractiveness (Borowicz et al., 2016; Godlewska-Majkowska, 2012, 2011), investment activity (Hoła and Nowobilski, 2018; Nazarczuk, 2013), innovation (Klóska, 2018; Kondratiuk-Nierodzińska, 2013), convergence and regional competitiveness (KSRR, 2030; Gołębiewski and Podlińska, 2015; Kowalewska, 2015; Łaźniewska et al., 2011; Murawska, 2010).
The key element of such studies, in terms of methodology, is an appropriate selection of variables that can describe the studied phenomenon. In most of the abovementioned reports, various aspects are combined, including:

- the economic aspect - financial capital, labour productivity, entrepreneurship, GDP per capita, structure of small and medium-sized enterprises;

- the demographic aspect - natural increase, migration, unemployment rate, level of education;

- the social aspect (quality of life) - state of the environment, leisure and tourism resources

- infrastructural aspect - transport accessibility, supply in gas, water and sewage system;

- construction industry aspect - value of construction and assembly production, employment, occupational accidents;

- scientific and research potential - public spending on research, development and innovation activities, $R \& D$ centres and facilities.

The characteristics listed above do not include territorial dimensions such as changes in land-use structure, but they can both be treated as a cause and an effect of such transformations. 
Therefore, it should be stated that from the perspective of contemporary challenges, the spatial management is the key factor of regional development (Łaźniewska, 2015).

The most dynamic changes in land use structure undeniably occur in urban and suburban zones. However, in recent years, intensive transformations have also been observed in typically rural areas (Senetra et al., 2014; Szymańska and Matczak, 2002). Decreasing the share of agricultural and forest areas to introduce new residential, industrial, service and transport functions can be an an important measure of the social and economic development.

The aim of the study was to develop a method for assessing the changes in the structure of agricultural and forest lands in regional and sub-regional administrative units using the available statistical data. The assessment results should enable to provide a comparative analysis for the studied units that can be applied in the analysis concerning their spatial and economic development, urbanisation level or even landscape changes.

The utilitarian subject of the research is the diversity assessment of regional spatial development for the construction purposes in Polish voivodeships, measured by changes in allocation of agricultural and forestry areas for investment purposes.

\section{METHODS}

The analysis applies to the agricultural and forestry land-use changes in 16 Polish voivodeships (first-tier administrative units) that occurred in the period of 2002-2017. The study includes a quantitative assessment of land transformation at the global level as well as the directions of changes broken down into residential, industrial, service and transport functions.

The comparative analysis used in the study utilizes the indicators to describe the intensity of a given phenomenon in the form of absolute or relative values. The set of the analyzed voivodeships can be described with the following twodimensional matrix of indicators (1):

$$
X_{W}=\left[\begin{array}{cccc}
X_{1.1} & \ldots & X_{n .1} & X_{7.1} \\
X_{1.2} & \ldots & X_{n .2} & X_{7.2} \\
\ldots & \ldots & \ldots & \ldots \\
X_{1.16} & \ldots & X_{n .16} & X_{7.16}
\end{array}\right]
$$

where: $W$ - voivodeship ( $\mathrm{W}=1,2 \ldots .16)$

$N$ - indicator used in the analysis $(\mathrm{n}+1$, $2, \ldots ., N)$
The data from the Local Data Bank for the period of 2003-2017 were used to define indicators that describe agricultural and forestry land use changes in the analyzed voivodships in the following categories:

1. Territorial division - subgroup of country geodetic areas, directions of use;

2. State and protection of natural environment:

- Subgroup of arable and forest land excluded from agricultural and forestry production, by type of land; Subgroup of arable and forest land excluded from agricultural and forestry production, by directions of use.

- The following indicators were calculated:

- The relative degree of changes in agricultural $\mathrm{X}_{1}$ (forestry $\mathrm{X}_{3}$ ) lands in a voivodeship in the period of 2003-2017 (2).

$$
X_{1(3)}=\frac{P_{A-E x(F-E x)}}{P w} \cdot 100
$$

where: $P_{A-E x(F-E x)}$ - the total area of agricultural (forest) lands in a voivodeship (W), subject to transformation for non-agricultural (non-forest) purposes in 2003-2017 [ha], $P_{W}$ - total area of a voivodeship (W) [ha]

- The absolute degree of changes in agricultural $X_{2}$ (forestry $X_{4}$ ) lands in a voivodeship for non-agricultural (non-forest) purposes in 2003-2017 (3).

$$
X_{2(4)}=\frac{P_{A-E x(F-E x)}}{P_{A(F)}} \cdot 100
$$

where: $P_{A-E x(F-E x)}-$ the total area of agricultural (forestry) lands in a voivodeship (W) subject to transformation for non-agricultural (non-forest) purposes in 2003-2017 [ha] $P_{A(F)}$ - agricultural (forest) land area in a voivodeship (W) in 2017 [ha]

The obtained indicator values were normalized in accordance to the formula (4):

$$
Z_{X 1(X 2, X 3, X 4)}=\frac{X_{1(2,3,4)}-\bar{X}_{1(2,3,4)}}{\sigma_{X 1(X 2, X 3, X 4)}}
$$

where: $Z_{X 1 . . n}$ - normalized indicator value

$X_{1 \ldots .}$-indicator value before normalization

$X_{1}-$ mean value in analysed set of objects

$\sigma-$ standard deviation of indicator values 
The obtained normalized indicators were a subject of a statistical data analysis - cluster analysis of the Statistica 13.3 software. It is based on grouping (agglomeration) the objects in accordance to the degree of their similarity. In a given group (called a cluster), there are objects similar to each other and - at the same time - different from the objects in other clusters (Wierzchon and Kłopotek, 2015). The measure of objects resemblance is a function of distance. In this case, the Euclidean distances were computed, according to the formula (5):

$$
d\left(W_{1}, W_{2}\right)=\sqrt{\sum_{n}\left(Z_{n 1}-Z_{n 2}\right)^{2}}
$$

where: $W_{1}$ and $W_{2}$-the analysed voivodeships $Z_{n 1}, Z_{n 2}-Z_{n}$ indicators for the voivodeships

Apart from the distance measure, the Ward's minimum variance clustering method (Ward 1963) was used to group similar voivodeships. The method is considered to be very effective, although it tends to produce small-sized clusters (Łaźniewska et al., 2011). A dendrogram is the graphical representation of objects agglomeration, where leaves represent individual observations and nodes - clusters. Nodes are located at a level corresponding to the degree of dissimilarity between clusters. The cluster analyses were performed separately for the indicators of the agricultural land use changes (ZX1 i ZX2) and forestry land use changes (ZX3, ZX4).

The available data describing the directions of agricultural and forest lands development excluded from agricultural and forestry production, were used to calculate the three additional indicators:

- The indicator of repurposing of agricultural and forest lands for residential development $\mathrm{X}_{5}(6)$

$$
X_{5}=\frac{\mathrm{P}_{\text {AF-res }}}{P_{\text {res }}} \cdot 100
$$

where: $P_{\text {AF-res }}$ - total area of agricultural and forest lands repurposed for residential development in the period of 2003-2017 [ha] $P_{\text {res }}$ - total area of residential lands in a voivodeship in 2017 [ha]

- The indicator of repurposing of agricultural and forest lands for industrial and service development $-\mathrm{X}_{6}(7)$

$$
X_{6}=\frac{P_{A F-i n d}}{P_{\text {ind }}} \cdot 100
$$

where: $P_{A F-\text { ind }}$ - total area of agricultural and forest lands repurposed for industrial and service development in 2003-2007 [ha] $P_{\text {ind }}$ - total area of industrial lands in a voivodeship in 2017 [ha].

- The indicator of repurposing of agricultural and forestry lands for roads and transport development $-\mathrm{X}_{7}(8)$

$$
X_{7}=\frac{P_{A F-\text { tran }}}{P_{\text {tran }}} \cdot 100
$$

where: $P_{A F-t r a n}-$ total area of agricultural and forest lands repurposed for roads and transport development in 2003-2007 [ha] $P_{\text {tran }}$ - total area of roads and transportrelated lands in a voivodeship in 2017 [ha]

In order to present the differences between voivodships concerning the changes of agricultural and forest land purpose, it was decided to perform normalization of the indicators $\mathrm{X}_{5}, \mathrm{X}_{6}$, $\mathrm{X}_{7}$ according to the maximum value in a given set, i.e. (9)

$$
Z_{X 5(X 6, X 7)}=\left(\frac{X_{5(6,7)}}{\max X_{5(6,7)}}\right)
$$

In order to present the spatial structure of repurposing the agricultural and forest land in individual voivodships, it was assumed that the total area of land allocated for residential, industrial and transport purposes correspond to $100 \%$ of all lands repurposed for non-agricultural and non-forestry uses. This is a simplified approach, used only for the purpose of this study, otherwise one would also have to include small areas of agricultural and forest land allocated for other purposes, e.g. surface waters and mineral sources excavation.

The spatial analysis and presentation of the obtained results were prepared with the use of ArcGIS 10.4.1. software (ESRI). 


\section{RESULTS}

Input data and calculated indicators concerning the changes of agricultural and forestry land for non-agricultural and non-forest purposes in 2003-2017 are presented in Table 1.

After analyzing the values of the $\mathrm{Z}_{\mathrm{x} 2}$ indicator representing the absolute degree of changes of agricultural lands in voivodeships for non-agricultural purposes, it was decided to divide the analysed units into four types:

- Type I - voivodeships with high intensity of agricultural land repurposing, $\mathrm{Z}_{\mathrm{x} 2} \geq 1$

- Type II - voivodeships with medium intensity of agricultural land repurposing, $1>\mathrm{Z}_{\mathrm{x} 2} \geq 0$

- Type III - voivodeships with low intensity of agricultural land repurposing, $0>Z_{x 2} \geq-0,5$

- Type IV - voivodeships with very low intensity of agricultural land repurposing, $\mathrm{Z}_{\mathrm{X} 2}<-0,5$

The spatial distribution of the voivodeships assigned to the specified types is presented in Figure 1. The greatest intensification of the changes in agricultural land was observed in the
Pomorskie and Śląskie Voivodeships, significant changes in Zachodnio-Pomorskie, Dolnośląskie, Małopolskie and Lubelskie, the lowest in partly traditionally agricultural regions of north-eastern Poland (Kujawsko-Pomorskie, WarmińskoMazurskie, Podlaskie, Lubelskie) but also in more developed regions (Mazowieckie, Opolskie).

The cluster analysis for the $\mathrm{Z}_{\mathrm{X} 1}$ and $\mathrm{Z}_{\mathrm{X} 2}$ indicators was applied to aggregate the voivodeships with similar level of agricultural land repurposing. Four identified clusters are presented in the dendrogram (Figure 2). The highest similarity was observed between the voivodeships in Cluster A-I: Kujawsko-Pomorskie, Opolskie, Podlaskie, Lubelskie (Table 2).

The values of the $\mathrm{Z}_{\mathrm{X} 4}$ indicator that represent the absolute degree of changes of forestry lands for non-forestry purposes, enabled to allocate the analysed voivodeships to one of the four types:

- Type 1 - voivodeships with high intensity of forestry land repurposing, $\mathrm{Z}_{\mathrm{X} 4} \geq 1$;

- Type 2 - voivodeships with medium intensity of forestry land repurposing $1>Z_{X 4} \geq 0$;

Table 1. Input data and obtained indicators concerning the changes of agricultural and forestry lands for other purposes in the analyzed voivodeships

\begin{tabular}{|c|c|c|c|c|c|c|c|c|c|c|c|c|c|c|}
\hline \multirow{3}{*}{ No } & \multirow{3}{*}{ Voivodeship } & \multicolumn{5}{|c|}{ Area [ha] } & \multicolumn{4}{|c|}{ Indicators [-] } & \multirow{2}{*}{\multicolumn{4}{|c|}{ Normalized indicators }} \\
\hline & & \multirow{2}{*}{$\begin{array}{l}\text { W } \\
P_{w} \\
\end{array}$} & \multicolumn{2}{|c|}{ Agricultural } & \multicolumn{2}{|c|}{ Forestry } & \multicolumn{2}{|c|}{$\begin{array}{l}\text { Repurposement } \\
\text { of agricultural } \\
\text { land }\end{array}$} & \multicolumn{2}{|c|}{$\begin{array}{l}\text { Repurposement } \\
\text { of forestry land }\end{array}$} & & & & \\
\hline & & & $P_{A-E x}$ & $P_{A}$ & $P_{F-E x}$ & $P_{F}$ & $x_{1}$ & $x_{2}$ & $x_{3}$ & $x_{4}$ & $Z x_{1}$ & $Z x_{2}$ & $Z x_{3}$ & $Z x_{4}$ \\
\hline 1 & dolnośląskie & 1994670 & 4277 & 862746 & 1142 & 612305 & 0.214 & 0.496 & 0.064 & 0.187 & 0.329 & 0.191 & 0.983 & 0.739 \\
\hline 2 & $\begin{array}{l}\text { kujawsko- } \\
\text { pomorskie }\end{array}$ & 1797134 & 859 & 990036 & 469 & 429605 & 0.048 & 0.087 & 0.019 & 0.109 & -1.063 & -1.063 & -0.558 & -0.031 \\
\hline 3 & lubelskie & 2512246 & 1629 & 1311774 & 151 & 573550 & 0.065 & 0.124 & 0.011 & 0.026 & -0.921 & -0.948 & -0.830 & -0.857 \\
\hline 4 & lubuskie & 1398793 & 2254 & 401130 & 523 & 711424 & 0.161 & 0.562 & 0.029 & 0.074 & -0.116 & 0.394 & -0.214 & -0.387 \\
\hline 5 & łódzkie & 1821895 & 4208 & 987419 & 1733 & 372238 & 0.231 & 0.426 & 0.114 & 0.466 & 0.468 & -0.022 & 2.723 & 3.519 \\
\hline 6 & małopolskie & 1518279 & 3642 & 651476 & 499 & 440846 & 0.240 & 0.559 & 0.014 & 0.113 & 0.542 & 0.385 & -0.720 & 0.009 \\
\hline 7 & mazowieckie & 3555847 & 3492 & 1649904 & 756 & 836080 & 0.098 & 0.212 & 0.080 & 0.090 & -0.642 & -0.680 & 1.561 & -0.218 \\
\hline 8 & opolskie & 941187 & 501 & 490605 & 288 & 258932 & 0.053 & 0.102 & 0.016 & 0.111 & -1.018 & -1.016 & -0.648 & -0.011 \\
\hline 9 & podkarpackie & 1784576 & 2110 & 591191 & 324 & 687992 & 0.118 & 0.357 & 0.016 & 0.047 & -0.475 & -0.235 & -0.650 & -0.650 \\
\hline 10 & podlaskie & 2018702 & 996 & 762600 & 275 & 631277 & 0.049 & 0.131 & 0.015 & 0.044 & -1.050 & -0.929 & -0.685 & -0.684 \\
\hline 11 & pomorskie & 1831034 & 8612 & 700424 & 614 & 683461 & 0.470 & 1.230 & 0.050 & 0.090 & 2.468 & 2.442 & -0.747 & -0.224 \\
\hline 12 & śląskie & 1233309 & 4899 & 449997 & 411 & 403765 & 0.397 & 1.089 & 0.035 & 0.102 & 1.857 & 2.010 & 0.006 & -0.105 \\
\hline 13 & świętokrzyskie & 1171050 & 1609 & 537854 & 321 & 335770 & 0.137 & 0.299 & 0.013 & 0.096 & -0.314 & -0.412 & -0.747 & -0.167 \\
\hline 14 & \begin{tabular}{|l} 
warmińsko- \\
mazurskie
\end{tabular} & 2417347 & 2213 & 875485 & 156 & 777517 & 0.092 & 0.253 & 0.005 & 0.020 & -0.698 & -0.554 & -1.023 & -0.918 \\
\hline 15 & wielkopolskie & 2982650 & 5008 & 1564481 & 1194 & 786783 & 0.168 & 0.320 & 0.052 & 0.152 & -0.059 & -0.347 & 0.591 & 0.392 \\
\hline 16 & $\begin{array}{l}\text { zachodnio- } \\
\text { pomorskie }\end{array}$ & 2289248 & 5906 & 857200 & 601 & 840435 & 0.258 & 0.689 & 0.026 & 0.072 & 0.693 & 0.784 & -0.300 & -0.407 \\
\hline
\end{tabular}

Explanation: W - voivodeship, $P_{W_{-}}$total area of a voivodeship, $P_{A-E x}\left(P_{F-E x)}-\right.$ the total area of agricultural (forest) lands in a voivodeship, $P_{A} P_{F)}$-agricultural (forest) land area in a voivodeship in $2017 \mathrm{X}_{1}\left(\mathrm{X}_{3}\right)$ - the relative degree of changes of agricultural (forestry $X_{3}$ ) lands in a voivodeship in the period of 2003-2017, $X_{2}\left(X_{4}\right)$ - the absolute degree of changes of agricultural (forestry) lands in a voivodeship for non-agricultural (non-forest) purposes in 2003-2017, $Z_{X 1 . .4}-$ normalized indicator value, 


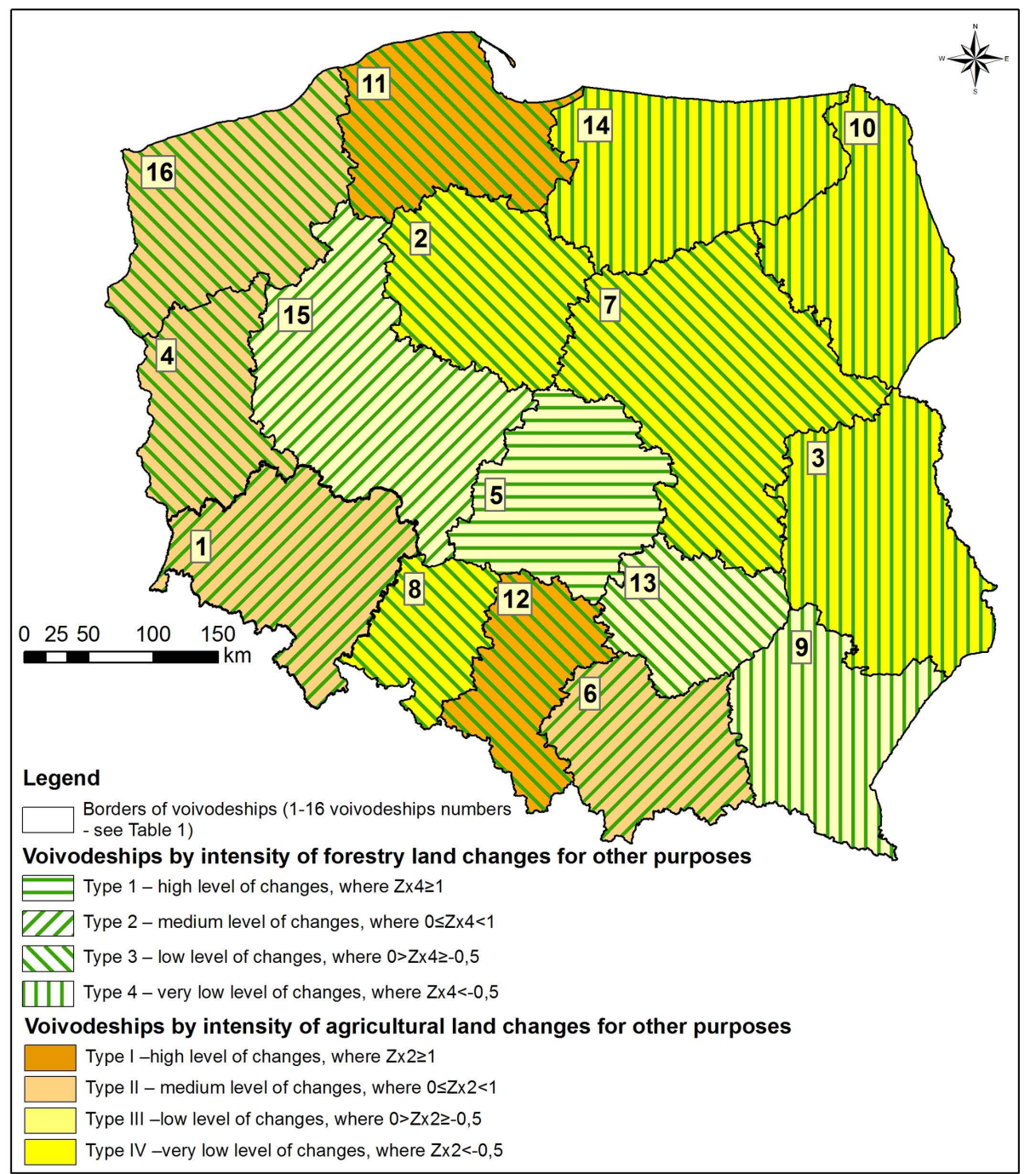

Fig. 1. Spatial distribution of the voivodeship types classified by the intensity of agricultural and forestry lands changes.

- Type 3 - voivodeships with low intensity of forestry land repurposing $0>\mathrm{Z}_{\mathrm{X} 4} \geq-0,5$;

- Type 4 - voivodeships with very low intensity of forestry land repurposing $Z_{\mathrm{X} 4}<-0,5$.

The location of the particular voivodeship types is presented in Figure 1. The relatively large forest land repurposement occurred only in the Łódzkie Voivodeship, while medium changes in the voivodeships: Wielkopolskie, Małopolskie and Dolnośląskie.

According to the results of cluster analysis (Figure 3, Table 2) for the indicators describing forestry land repurposing $\left(\mathrm{Z}_{\mathrm{X} 3}\right.$ and $\left.\mathrm{Z}_{\mathrm{X} 4}\right)$ the most similar voivodeships are those assigned to the $\mathrm{F}-1$ cluster (Lubelskie, Warmińsko-Mazurskie, Podkarpackie, Podlaskie). The lowest level of similarity was found for the Lódzkie Voivodeship. This is due to the relatively large area being the subject of land-use changes.
In the majority of the voivodeships, the structure of transformed agricultural and forest lands according to direction of changes is very similar (Table 3).

The largest areas were mostly repurposed for the development of residential areas $(>50 \%)-$ Figure 4 . The distinguishable administrative units are:

- the Kujawsko-Pomorskie Voivodeship, where the most of agricultural and forest areas were designated for development of industrial areas (48.4\%), while for residential areas - 46.2\%; similarly in the Dolnośląśkie Voivodeship $46.1 \%$ for industrial land-use and $48.9 \%$ for residential, the Łódzkie Voivodeship - 45.1\% and $49.8 \%$, respectively;

- voivodeships, where larger part of agricultural and forest areas were designated for development of industrial area than to residential area: 


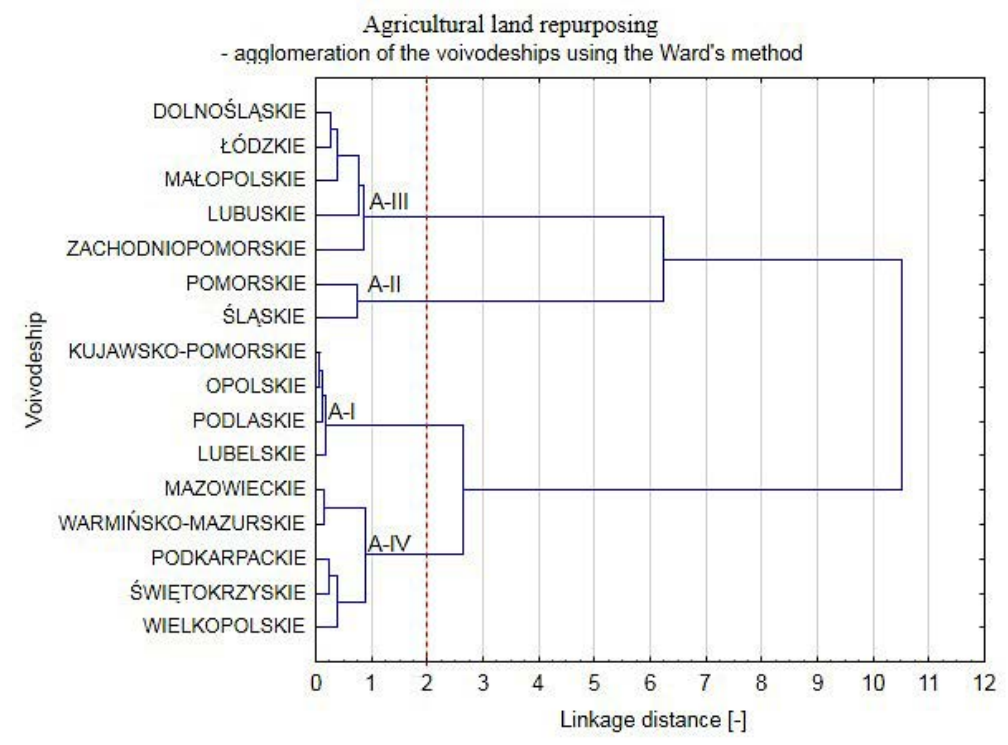

Fig. 2. Dendrogram - the voivodeships aggregated by similarity in the intensity of agricultural lands repurposing $\left(\mathrm{Z}_{\mathrm{x} 1}\right.$ and $\left.\mathrm{Z}_{\mathrm{X} 2}\right)$

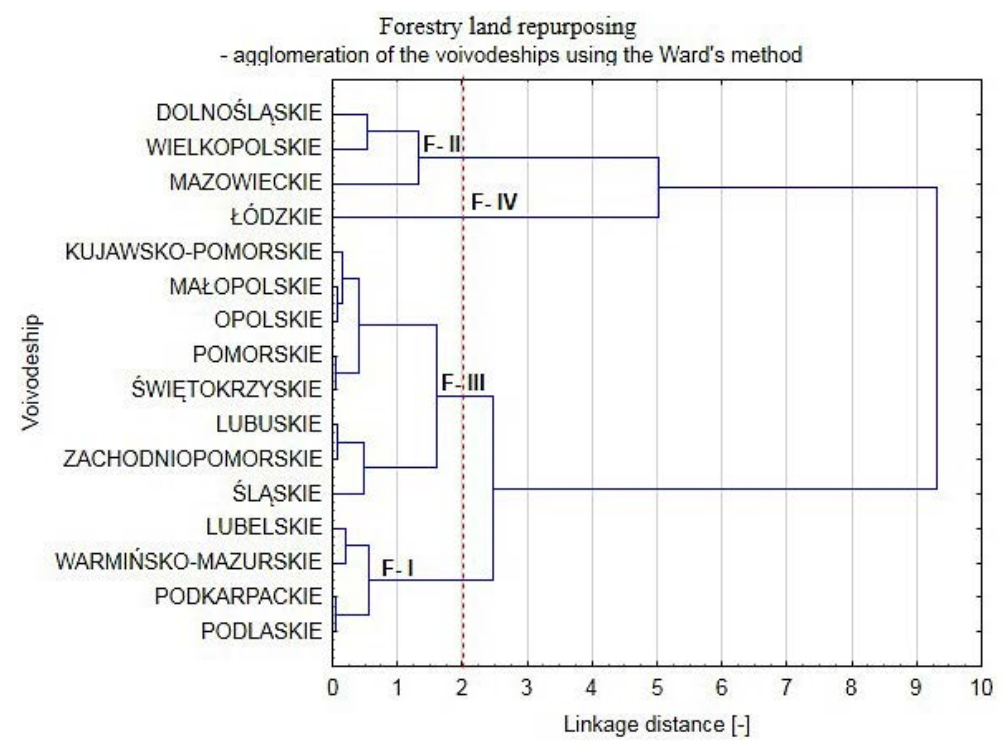

Fig. 3. Dendrogram - the voivodeships aggregated by similarity in the intensity of forestry lands repurposing $\left(\mathrm{Z}_{\mathrm{X} 3}\right.$ and $\left.\mathrm{Z}_{\mathrm{X} 4}\right)$

the Kujawsko-Pomorskie Voivodeship 48,4\% and $46,2 \%$, the Dolnoślaśkie Voivodeship $46.1 \%$ and $48.9 \%$, the Łódzkie Voivodeship $45.1 \%$ and $49.8 \%$ respectively;

- voivodeships with a significant share of agricultural and forest lands repurposed for roads and transport development: the Podlaskie (15.5\%) and the Lubelskie Voivodeship (11.1\%).

The spatial diversity analysis in terms of the intensity in allocation of agricultural and forest lands for other purposes shows that:
- the highest intensity of land repurposement for residential development took place in Pomerania (the Zachodnio-Pomorskie and Pomorskie Voivodship), while the lowest in the Opolskie and Kujawsko-Pomorskie Voivodships;

- the highest intensity of land repurposement for industrial development was observed in the Łódzkie Voivodeship, Pomorskie and Lubuskie; whereas the lowest in the south of Poland (Opolskie, Śląskie, Świętokrzyskie, Małopolskie, Podkarpackie). 
Table 2. Clusters of voivodeships with similar agricultural an forestry lands repurposing intensity

\begin{tabular}{|l|l|c|}
\hline \multicolumn{1}{|c|}{ Cluster } & \multicolumn{1}{|c|}{ Voivodeships } & \multicolumn{1}{|c|}{$\begin{array}{c}\text { the Euclidean distance between } \\
\text { voivodeships aggregated in clusters }\end{array}$} \\
\hline \multicolumn{1}{|c|}{ Agricural lands repurposed for non-agricultural purposes } \\
\hline A-IV & $\begin{array}{l}\text { mazowieckie, warmińsko-mazurskie, podkarpackie, świętokrzyskie, } \\
\text { wielkopolskie }\end{array}$ & 0,88 \\
\hline A-III & dolnośląskie, tódzkie, małopolskie, lubuskie, zachodniopomorskie & 0,86 \\
\hline A-II & pomorskie, śląskie & 0,75 \\
\hline A-I & kujawsko-pomorskie, opolskie, podlaskie, lubelskie & 0,17 \\
\hline & \multicolumn{1}{|c|}{ Forest lands repurposed for non-forestry purposes } \\
\hline F-IV & lódzkie & $\begin{array}{l}\text { very high degree of dissimilarity, } \\
\text { the shortest distance 5,03 }\end{array}$ \\
\hline F-III & $\begin{array}{l}\text { kujawsko-pomorskie, małopolskie, opolskie, pomorskie, } \\
\text { świętokrzyskie, lubuskie, zachodniopomorskie, śląskie }\end{array}$ & 1,598 \\
\hline F-II & dolnośląskie, wielkopolskie, mazowieckie & 1,335 \\
\hline F-I & lubelskie, warmińsko-mazurskie, podkarpackie, podlaskie & 0,559 \\
\hline
\end{tabular}

Table 3. Input data and obtained indicators concerning agricultural and forestry land repurposement according to the designation

\begin{tabular}{|c|c|c|c|c|c|c|c|c|c|c|c|c|c|}
\hline \multirow{2}{*}{ No } & \multirow{2}{*}{ Voivodeship } & \multicolumn{6}{|c|}{ Area [ha] } & \multicolumn{3}{|c|}{ Indicators [-] } & \multicolumn{3}{|c|}{ Normalized indicators } \\
\hline & & $P_{\text {AF-res }}$ & $P_{\text {res }}$ & $\mathrm{P}_{\mathrm{AF}-\mathrm{ind}}$ & $\mathrm{P}_{\text {ind }}$ & $\mathrm{P}_{\mathrm{AF}-\operatorname{tran}}$ & $P_{\text {tran }}$ & $X_{5}$ & $\mathrm{x}_{6}$ & $x_{7}$ & $z_{x 5}$ & $z_{x 6}$ & $z_{x 7}$ \\
\hline 1 & dolnośląskie & 1695 & 22885 & 1597 & 14609 & 174 & 72313 & 7.406 & 10.932 & 0.241 & 0.248 & 0.475 & 0.476 \\
\hline 2 & kujawsko-pomorskie & 475 & 21013 & 498 & 6853 & 56 & 50179 & 2.260 & 7.267 & 0.112 & 0.076 & 0.316 & 0.221 \\
\hline 3 & lubelskie & 955 & 11156 & 272 & 4166 & 153 & 68151 & 8.560 & 6.529 & 0.224 & 0.286 & 0.284 & 0.444 \\
\hline 4 & lubuskie & 1382 & 9816 & 559 & 3289 & 186 & 39474 & 14.079 & 16.996 & 0.471 & 0.471 & 0.740 & 0.932 \\
\hline 5 & łódzkie & 1741 & 21908 & 1575 & 6847 & 177 & 54751 & 7.947 & 23.003 & 0.323 & 0.266 & 1.000 & 0.640 \\
\hline 6 & małopolskie & 2553 & 25684 & 285 & 8114 & 97 & 47360 & 9.940 & 3.512 & 0.205 & 0.333 & 0.153 & 0.405 \\
\hline 7 & mazowieckie & 2125 & 53510 & 686 & 12214 & 99 & 105992 & 3.971 & 5.616 & 0.093 & 0.133 & 0.244 & 0.185 \\
\hline 8 & opolskie & 242 & 10686 & 56 & 4948 & 27 & 31124 & 2.265 & 1.132 & 0.088 & 0.076 & 0.049 & 0.171 \\
\hline 9 & podkarpackie & 1239 & 15539 & 208 & 5216 & 101 & 51895 & 7.973 & 3.988 & 0.195 & 0.267 & 0.173 & 0.385 \\
\hline 10 & podlaskie & 461 & 8304 & 182 & 2861 & 118 & 56085 & 5.551 & 6.361 & 0.210 & 0.186 & 0.276 & 0.416 \\
\hline 11 & pomorskie & 5796 & 21221 & 1111 & 5910 & 261 & 51627 & 27.313 & 18.799 & 0.505 & 0.914 & 0.817 & 1.000 \\
\hline 12 & śląskie & 3030 & 50159 & 666 & 21541 & 206 & 53747 & 6.041 & 3.092 & 0.383 & 0.202 & 0.134 & 0.758 \\
\hline 13 & świętokrzyskie & 638 & 9217 & 130 & 3977 & 39 & 32483 & 6.922 & 3.269 & 0.120 & 0.232 & 0.142 & 0.238 \\
\hline 14 & $\begin{array}{l}\text { warmińsko- } \\
\text { mazurskie }\end{array}$ & 866 & 14309 & 484 & 3480 & 52 & 61164 & 6.052 & 13.908 & 0.085 & 0.202 & 0.605 & 0.168 \\
\hline 15 & wielkopolskie & 1655 & 33922 & 840 & 10351 & 135 & 91109 & 7.879 & 8.115 & 0.148 & 0.264 & 0.353 & 0.293 \\
\hline 16 & $\begin{array}{l}\text { zachodnio- } \\
\text { pomorskie }\end{array}$ & 3320 & 11111 & 1017 & 9213 & 221 & 57285 & 29.880 & 11.039 & 0.386 & 1.000 & 0.480 & 0.763 \\
\hline
\end{tabular}

Explanation: $\mathrm{P}_{\mathrm{AF}-\mathrm{res}}\left(\mathrm{P}_{\mathrm{AF}-\text { ind, }} \mathrm{P}_{\mathrm{AF}-\mathrm{tran}}\right)$ - total area of agricultural and forest lands repurposed for residential development (industrial, roads and transport) in the period of 2003-2017, $\mathrm{P}_{\text {res }}$ - total area of residential lands (industrial, roads and transport) in a voivodeship in 2017, $\mathrm{X}_{5}$ - the indicator of repurposing of agricultural and forest lands for residential development (industrial, roads and transport), $Z_{X 5-7}-$ normalized indicator value.

- the highest intensity of agricultural and forest land repurposement for industrial development was observed in Pomerania (the Pomorskie and Zachodnio-Pomorskie Voivodeships), and in the Lubuskie Voivodeship, while the lowest, in the Opolskie and the WarmińskoMazurskie Voivodeships (Fig. 4).

\section{CONCLUSIONS}

The study of the intensity of land transformations in the years 2003-2017 indicates the existence of zone distribution in the voivodeships. This is especially evident in the case of agricultural land repurposement. The intensity 


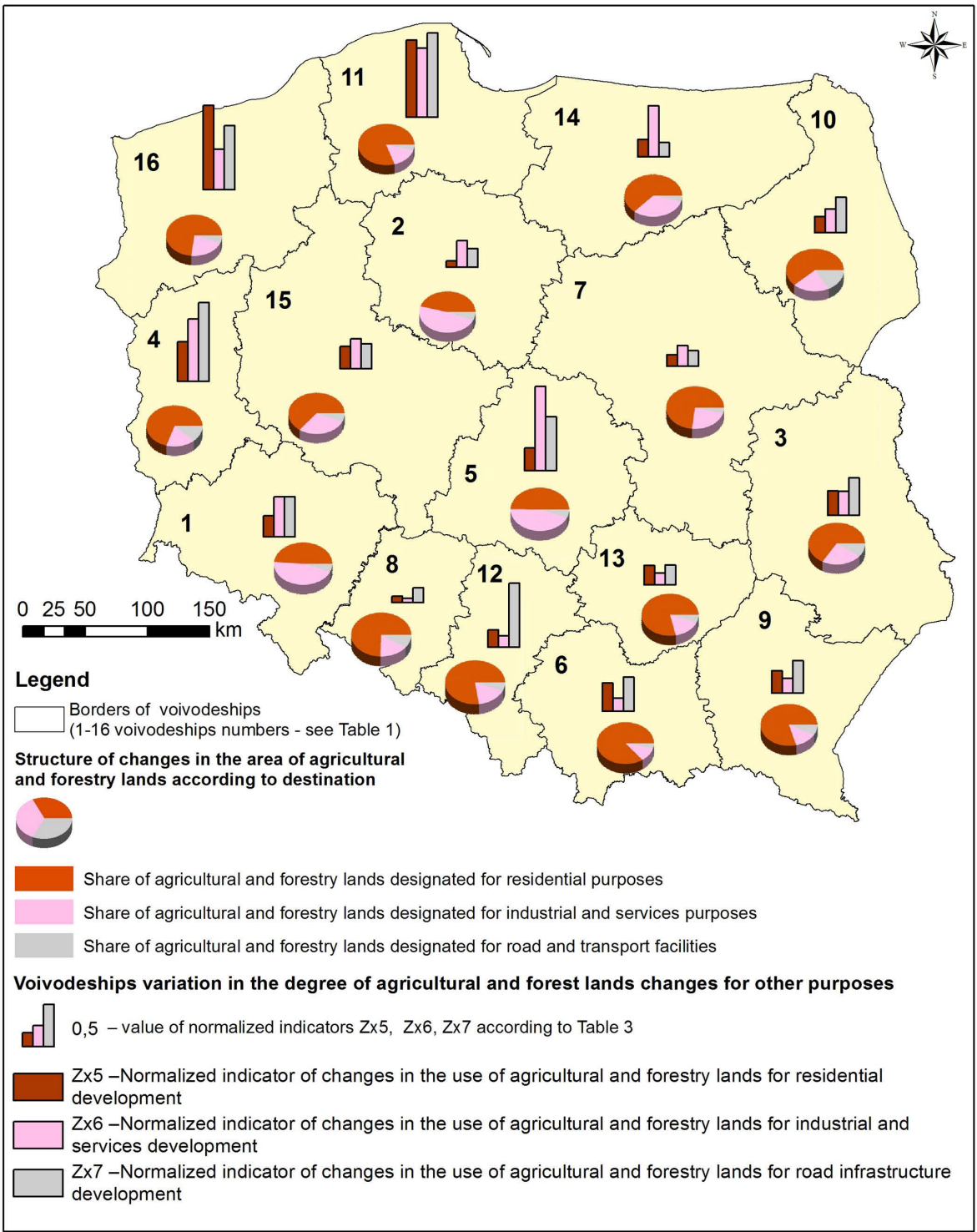

Fig. 4. The voivodeships according to directions of agricultural and forest lands repurposement.

of changes was highest in the west and lowest in the east regions of Poland. This depiction is confirmed by other surveys on regional development (Łaźniewska, 2015; Nazarczuk, 2013; Murawska, 2010) that demonstrate high diversity in terms of the development potential and investment attractiveness of regions, especially between the voivodeships of the western and the north-eastern Poland. However, some discrepancy exists in the assessment of the Mazowieckie Voivodeship, which is highly rated in economical rankings (Klóska, 2018; Drabarczyk, 2017), but in the case of land use changes, it was evaluated at a lower position.

A few voivodeships differ from others by exhibiting an increased activity in agricultural and forestry lands repurposement. Those changes in land use are not limited to the transformation of the land into residential areas, but also into industrial zones (the Łódzkie, Pomorskie and Lubuskie Voivodeships) or areas designated for road transport development (the Pomorskie, Lubuskie and Śląskie Voivodeships). This fact can serve as evidence of both the growing investment activity and in some cases, a catching-up process.

The study presents the statistical analysis concerning the land-use changes for non-agricultural and non-forest purposes in long-term dimension and high level of generalisation. However, the presented methods are applicable not only at the regional level, but also at the subregional one. It is a useful tool in the analysis of land-use changes concerning the suburban areas or so called problem areas, the development of which is falling behind in terms of meeting infrastructure and service needs. The available 
statistical data enables to analyse the issue in dynamic terms, comparing the land-use changes during shorter periods of time (e.g. five-year periods) than in the in the presented studies.

\section{REFERENCES}

1. Borowicz A., Kostyra M., Dzierżanowski M., Szultka S. (Eds.), Wandałowski M. 2016. Investment attractiveness of Polish voivodships and sub-regions. Instytut Badań nad Gospodarką Rynkową. Gdańsk [in Polish].

2. Drabarczyk K. 2017. Sustainable development of voivodeships - comparative analysis. Zeszyty Naukowe Politechniki Częstochowskiej Zarządzanie, 25(2), 23-34 [in Polish].

3. Dunnell K. 2009. National Statistician`s article: measuring regional economic performance, Economic \& Labour Market Review, 3(1), pp. 18.

4. Godlewska-Majkowska H. 2012. Investment attractiveness of Polish regions as a source of entrepreneurial competitive advantages. Studia i Analizy Instytut Przedsiębiorstwa. Oficyna Wydawnicza SGH. Warszawa [in Polish].

5. Godlewska-Majkowska H. 2011. Investment attractiveness of Polish regions and regional entrepreneurship - a comprehensive approach. Studia i Analizy Instytutu Przedsiębiorstwa, Oficyna Wydawnicza Szkoła Główna Handlowa w Warszawie, Warszawa, 25-48 [in Polish].

6. Gołębiewski J., Podlińska O., 2015: The competitiveness of Polish regions and the European Union. In: Problemy rozwoju regionalnego i lokalnego w Polsce. Wydawnictwo Urzędu Miejskiego w Pułtusku, Pułtusk, 11-21 [in Polish].

7. Hoła B., Nowobilski T. 2018. Classification of Polish voivodeships with regard to selected indicators that characterize the construction industry. Scientific Review- Engineering and Environmental Sciences, 27(3). SGGW, Warszawa, 310-318 [in Polish].

8. Klóska R. 2018. Pre-discussion about the classification of provinces in Poland according to the innovation level. Ekonomiczne Problemy Usług no 2/2018 (131), t.1. Wydawnictwo Naukowe Uniwersytetu Szczecińskiego. Szczecin, 159-167 [in Polish].

9. Kondratiuk-Nierodzińska M. 2013. Regional innovation systems and competitiveness of voivodeships in Poland. Wydawnictwo Uniwersytetu w Białymstoku. Białystok 2013, pp. 308 [in Polish].

10. Kowalewska M.D. 2015. Regional differences in the level of economic development in Poland. In: Problemy rozwoju regionalnego i lokalnego w Polsce. Wydawnictwo Urzędu Miejskiego w Pułtusku, Pułtusk, 48-53 [in Polish].

11. KSRR 2030. National Strategy of Regional Development 2030. Available on line: https://archiwum. miir.gov.pl/media/67208/KSRR_17_12_2018_projekt.pdf. [in Polish].

12. Łaźniewska E., 2015. Regional Development and Spatial Planning. Biuletyn KPZK. Copyright by PAN, Komitet Przestrzennego Zagospodarowania Kraju, 144-161. [in Polish].

13. Łaźniewska E., Górecki T., Chmielewski R. 2011. Regional Convergence. Uniwersytet Ekonomiczny w Poznaniu. Poznań [in Polish].

14. Murawska A. 2010. Classification of provinces in terms of economic development by means of taxonomic methods. Polskie Stowarzyszenie Zarządzania Wiedzą. Seria: Studia i Materiały, no. 33, 211-221 [in Polish].

15. Nazarczuk J. M. 2013. Development potential and investment activity of Polish voivodships and subregions. Wydawnictwo UWM. Olsztyn [in Polish].

16. Senetra, A., Szczapańska, A., WasilewiczPszczółkowska M. 2014. Analysis of changes in the land use structure of developed and urban areas in Eastern Poland. Bulletin of Geography. Socioeconomic Series, No. 24, Nicolaus Copernicus University Press, Toruń, 219-230. DOI: http://dx.doi. org/10.2478/bog-2014-0024.

17. Szymańska, D., Matczak, A., 2002. Urbanization in Poland: tendencies and transformation. European Urban and Regional Studies. SAGE publications: London, Thousand Oaks, CA, New Delhi, 39-46. DOI: http://dx.doi.org/10.1177/096977640200900104. [in Polish].

18. Ward, J. H., Jr., 1963. Hierarchical Grouping to Optimize an Objective Function, Journal of the American Statistical Association, 58: 301, 236-244, DOI: 10.1080/01621459.1963.10500845.

19. Wierzchoń S., Kłopotek M. 2015. Cluster analysis algorithms. Wydawnictwo Naukowe PWN, Warszawa [in Polish]. 